THE UNINVITED RESEARCHER IN INDIAN COUNTRY: PROBLEMS OF PROCESS AND PRODUCT CONDUCTING RESEARCH AMONG NATIVE AMERICANS*

\title{
Robert John
}

University of Kansas

Mid-American Review of Sociology, 1990, Vol. XIV, No. 1-2:113-133.

This paper discusses what a researcher can expect when doing qualitative research in an American Indian community. Despite an attempt to adequately prepare for fieldwork, the author found that the research process differed in important respects from the qualitative methods literature. The paper chronicles key differences concerning gatekeepers and the research bargain, establishing rapport and gaining acceptance, the roles assigned to the researcher, the role of key informants and brokers, and several uniquely Indian processes the author experienced. The paper concludes with a summary of salient characteristics of research among American Indians and argues that such research takes longer, the research bargain is a matter of constant negotiation, gatekeepers are ubiquitous within the community, and the researcher needs to be prepared to make some accommodations to his or her hosts.

There are many reasons for choosing to employ qualitative methods in social science research. Even the most quantitatively-oriented social scientist recognizes, if grudgingly, the role that qualitative methods play in "exploratory research." A qualitative research approach also has achieved acceptance when the research focus is explicitly cross-cultural, especially if the researcher wishes to know about a group on their own terms.

In this instance my research project met both of these generally recognized conditions. In particular, I realized that academics know very little about Native American aging. Although I had studied the available literature about Native American aging, prior to entering the field I knew very little about the community and nothing about the lives of the elders I wished to study. ${ }^{1}$ Moreover, the particular topic of my research, the operation of an elders' informal support network, had received even less attention. Dutifully, I set about learning what I could about how to conduct a qualitative research project.

*Partial support for this study was provided by a National Institute on Aging Traineeship awarded through the Midwest Council for Social Research in Aging. I would like to thank Stuart Shafer, Sandra Albrecht, Norman Yetman and Lewis Mennerick for their assistance, suggestions, and encouragements. 


\section{PRE-FIELDWORK PHASE OF THE PROJECT}

During the pre-fieldwork phase of the project, I surveyed the literature on fieldwork techniques in order to familiarize myself with what a researcher might expect to encounter. Although I studied primers on conducting fieldwork (Becker 1970; Lofland 1971; Bogdan 1972; Bogdan and Taylor, 1975), read several classic studies (Wiseman 1970; Stack 1974), and located a few articles about doing fieldwork among Native Americans (Maynard 1974; Trimble 1977), in retrospect, the pre-fieldwork phase of the project did not prepare me very well for the experience. There is a tendency for everyone
who is relatively inexperienced in fieldwork to feel that one no fixed number of techniques, enter the field and go through a series of events that follow a pattern that has the that follow a pattern that has been documented in the works on qualitative methods. I attribute this impression to the social science predisposition to formalize and categorize, reducing complex processes to abstract caricatures, embodied in typologies, stages, or ideal types. Indeed, most of the literature on qualitative methods succumbs to the temptation to offer a blueprint to researchers. ${ }^{2}$ Even when authors warn against this misconception, the sheer amount of space devoted to the roles, patterns, stages, and techniques of participant observation overshadow the fund, stages, and techniques of fieldwork; namely that each situation is unique and there are not many specialized skills that are prerequisites for doing adequate research. In fact, I will risk the censure of my colleagues and say that there are no rules of fieldwork beyond those that people of average sensitivity employ in everyday social interaction, combined with a compulsion to record as much of the experience as possible.

Although a number of works attempt to characterize the stages of a fieldwork project and identify what takes place at each stage, the description provided by Rosalie Wax (1971) most accurately describes the experience I had, perhaps because many of her insights came from fieldwork conience among Native Americans. In comparight came from fieldwork conducted of participant observation (B. method by placing it within (hecer 1970) that feel constrained to defend the (i.e check placing it within the universe of discourse of quantitative methods (i.e., checking the frequency and distribution of the phenomena, constructing a model of the social system, and rechecking and rebuilding models), Rosalie Wax (1971, p. 16) characterizes the process simply:

First, there is the stage of initiation or resocialization, when the fieldworker tries to involve himself in the kinds of relationships which will enable him to do his fieldwork--the period during which he and his hosts work out or develop the kinds and varieties of roles which he and they will play. Second, there is the stage during which the fieldworker, having become involved in a variety of relationships, is able to concentrate on and do his fieldwork. Third, there is the postfield stage, when the fieldworker finishes his report.
According to Wax, it is the first stage of the project that is most important because it is during the first stage that the fieldworker finds, is offered, and accepts the lines of communication and the social vantage points through and from which he or she will make his observations and will be permitted to participate. It is also during this stage that she or he will find out whether or not she/he will be able to do the work he or she wishes to do. And, quite frequently, it is during this stage that the character, scope, and emphasis of his/her problem or investigation is determined. I found that this characterization of the first stage is accurate for research among American Indians.

Wax claims that the first stage of "involvement-seeking" is the most neglected in the literature, and it is this stage upon which I will focus. In discussing my fieldwork experience I will follow the suggestion made by Becker (1970) to give an account of the "natural history" of the project. However, my understanding of the first stage was influenced by my reading of the qualitative methods literature prior to entering the field. Since I entered the field with a set of expectations and concepts derived from this body of literature I will also address a number of these issues.

\section{ROLE OF THE RESEARCHER}

The role that I chose, that of participant-as-observer, is identified as the "master-role" by Raymond Gold (1969, p. 32). In this role both the observer and the informant are aware that theirs is a field relationship, and the identity and general purpose of the researcher are known. In particular, the role of participant-as-observer eliminated the problem of playing a disguised role and gave me greater freedom to ask questions. ${ }^{5}$

This role also gave me greater freedom to record what I was told. However, even this freedom was constrained to some degree. In accordance with much advice in the literature, I planned to record as much of my experience as possible on a portable tape recorder. Certainly, in the abstract, using a tape recorder is the best way to document a fieldwork experience. However, several of my earliest contacts either refused to be recorded or told me that the presence of a recorder would bother people, and I quickly decided never to use one while talking with people. In this setting, I believe that a recorder would have interfered with the ability of respondents to be candid and confide in me since they are suspicious of social scientists and wary of the sort of permanent record an audio tape provides (see Curley 1979, p. 225).

Instead, I took notes wherever possible--especially during interviews at formal social service agencies, during my extended interviews with individuals about their family life, and during the public meetings I attended--all of which were consistent with the role I chose. In addition to the notes, whenever I got in my car to drive somewhere, and particularly during the hour-long drive to and from the reservation, I would record observations that I was unable to transcribe at the time they occurred on a portable tape recorder I had in the 
car. Since I also had a cassette deck in the car, I was able to refine these accounts in the following manner while commuting.

After I had recorded all I could remember of a conversation, I would play the tape on the car cassette deck, stopping it whenever I remembered something that I had neglected or passed over, and recorded additional comments on a second, portable tape recorder I had in the car. This was a very effective technique, especially in the early phase of the project when the amount of new information was nearly overwhelming. This technique enabled me to rework my "fieldnotes" while the experiences were still fresh in my mind.

\section{GATEKEEPERS AND THE RESEARCH BARGAIN}

Following the advice of Trimble (1977, p. 172) to work through the tribal political structure, on my first trip to the reservation I went to the Tribal Administrative Office and asked to speak with the Tribal Chairperson. I explained the purpose of my visit and the general nature of my project to Big Man, the Tribal Chairperson. The only condition that he put on my doing the project was that I provide tribal officials with "a copy of whatever you write."

I had only spoken with the Tribal Chairperson for a few minutes before he introduced me to the tribal planner, John Morgan, an Anglo who had worked for the tribe for over five years. One of the first questions Morgan asked concerned my relationship to another researcher who had caused a great deal of controversy among traditionalists in the tribe a few years prior to the start of my project. He asked the question in a leading manner, but since I was well aware of the details of the incident and could truthfully state that I had no association with the person I was able to avoid a fatal debility. In fact, we established an instant rapport once I told him of a problem that I had with the person. After this I talked with him for nearly two hours, at first about my project but afterward about the reservation community. On several occasions during the course of our conversation he expressed some concern that I portray essentially "up-beat, positive things and not focus on the negative things." At the time, this comment gave me some concern that there might be an expectation or attempt on his part to influence the study.

During our lengthy conversation, he suggested that I get to know the director of the Senior Citizen's Title VI Nutrition Program, become involved with the Title VI Program Senior Citizen Advisory Committee, attend their next monthly meeting, and said "perhaps you can be useful to the tribe in that way." In order to acquaint me with his view of the situation the tribal planner told me that there were several problems that the program currently was experiencing and I might be able to assist in their solution. ${ }^{6} \mathrm{He}$ told me that the reservation was one of the few Indian reservations that had a meals program for the elderly that served more meals on wheels than were served at the congregate meal site. According to him, only one other tribe in the United States served more "home delivered" meals than congregate meals. $\mathrm{He}$ identified this as a problem because of the great push by the federal government to make such programs efficient (i.e. cut costs), and that pressure to reduce home deliveries and increase the number of congregate meals had been brought to bear.

He also told me that there had been problems with the Advisory Committee because of their desire to "control" the senior programs. In 1983, the federal government changed the nature of the responsibilities of the "Advisory Council," also changing the name of the body from council to committee, so that they were clearly serving in an advisory rather than an administrative capacity.

I was given a lot of disparate pieces of information about a number of things that, to my uninitiated ear, did not fit together in any coherent portrait of the community. John also gave me a map of the reservation and a copy of the results of a survey of elders. However, more important than the specific information I was given, I learned that I would be able to conduct the study. In comparison with another experience I had at a nearby reservation, where there was a reserved acceptance and clear indication that I would have to go through tribal council channels giving details of what I wanted to do, needing to obtain formal approval before I could begin the project, my experience at the tribal administrative office was very positive and I left with the feeling that I would be able to proceed with the study without delay. Looking back, I left this first contact with a sense of elation and a misperception of having cleared the "gatekeepers" and struck a "research bargain" with minimal problems.

\section{ESTABLISHING RAPPORT}

On the next day I returned to the reservation to talk with Northern Drummer, Director of the Title VI Nutrition Program, in order to get information about the activities she administered. During our initial meeting she told me about the program in general but we also talked about the home delivered meals and the advisory committee, since these had been identified as "problems."

After she informed me of the schedule of the "home delivered" meals, I offered to help deliver them in order to see first-hand what had been defined as a problem. I also hoped to come into contact with some tribal elders and be shown around the reservation. Although I did not think that delivering the meals would be useful in establishing firm contacts, I thought that at least my presence on the reservation would be known. Therefore, I volunteered to help with the "home-delivered" meals a few days later. When I told Northern Drummer that I wanted to do a research project on the family life of tribal elders, she said that "people do not want to have any more needs assessments done." She contended that they were "tired of filling out forms and having people pry into their affairs."

To substantiate her claim she showed me several questionnaires that were part of a larger survey of their service population, known as the "Central Intake Form," to which thirty-seven people responded. In particular, she 
showed me four responses from people who had refused to fill out the questionnaire. One person said that the type of questions that were asked were "too personal.... You don't have the right to ask these questions." Another responded that "it's none of your business." A third person wrote "I'm getting dam [sic] tired of filling out forms an [sic] I'm not getting nothing out of it," although this person said that he might have been willing to respond to the questions if someone had come and seen him and asked. Another person said that they would not fill it out because they were not a "senior citizen."

Based on information she provided, the thirty-four people over sixty years old who responded with completed questionnaires comprised at least forty-five percent of the senior population. After seeing this survey I realized that illiteracy or a lack of fluency in English would not be a major problem in conducting my study as it would be among some other Native American groups.

On the day I helped deliver meals it so happened that the regular driver had hurt his ribs and had not come to work so Northern Drummer was filling in and had asked one of the tribal elders who worked part-time for the Title VI program to accompany us in making the deliveries. Northern Drummer told me that she had asked him along because she thought I might like to get to know him since he was one of the seniors who lived on the reservation. I think she presumed that this would get my project going but, since I had not talked in great detail about the precise nature of my project as the qualitative methods literature recommends, Northern Drummer did not realize that I had prepared a questionnaire and wished to collect information in a systematic way. I was glad to get to talk with Wind Rider during the trip but did not attempt to do more than make his acquaintance, in hopes that I would be able to interview him in the future.

We traveled forty-nine miles in delivering eighteen meals that day, and I charted the location of where the meals were delivered on a copy of the reservation map that John gave me. During the trip Northern Drummer repeated that "people do not want to have any more needs assessments done." However, she said that she did not know whether or not a couple of her aunts would talk to me but that she would ask. I.told her that I appreciated her offer but that I did not want her to do it now because I wanted to try to figure out what was going on before I interviewed anyone.

Although I did learn something by going on the home deliveries, I realized that the two hours per trip and the necessity of keeping a schedule would preclude getting to know any of the seniors on more than a superficial basis or getting more information than the hearsay provided by the person I accompanied. Since a researcher cannot simply go up to a house, ring the doorbell and explain the purpose of the intrusion with some expectation that the person will participate in the research, a different research strategy was necessary in order to establish rapport.

Since the only place that elders congregate on a daily basis is the senior center meal site, I decided to get to know some of the seniors who ate meals there while I became more familiar with the formal social service agencies on the reservation. Therefore, during the course of my fieldwork I spent many hours "visiting" with people before, during, or after lunch at the meal site During this stage of my fieldwork experience, a typical day of fieldwork would include a morning interview with someone at one of the social service agencies about their program, eating lunch at the senior citizen center, and then "visiting" with some of the tribal elders or going to talk with a tribal official or worker. This strategy was a good one, since I came to know what was going on from a number of perspectives very quickly.

I found, as Bogdan and Taylor (1975, p. 46) did, that "probably the easiest way for observers to gain rapport...is to establish what they have in common" with their hosts. "Visiting" with people and "sharing" common experiences was a major aspect of establishing rapport. Our gardens, repair problems around our homes, car troubles, job problems, and children were all common topics of conversation. But a parallel process of gaining acceptance was taking place as I was finding out about the community and social service setting.

\section{BEING TAUGHT ONE'S PLACE}

Two weeks after entering the field I attended my first Title VI Senior Citizen's Advisory Committee meeting. Although a number of issues were discussed, the major piece of business was to complete revision of the group's constitution and by-laws in order to bring them in line with new federa regulations designed to reduce the "power" of the committee within the operation of the Title VI program. Basically, this required the modification of the language of the constitution and by-laws to eliminate ambiguities and clearly state that the purpose of the group was to advise and not run the program. Although the language changes eliminated the power of the "advisory council" to oversee the "day to day operations of the program," the change that elicited the most resistance from those in attendance concerned the reduction of the age of eligibility for the program from age sixty to fifty-five.

After years of lobbying by advocates for Indian elders that Indian elders have greater needs at an earlier age than non-minority.group elders (National Indian Council on Aging 1981; Red Horse 1982), federal guidelines finally permitted the Title VI Nutrition Program to reduce the age of eligibility and serve Indian elders over fifty-five. During the meeting it became clear that the advisory committee had opposed the change although it had been unilaterally made by the tribal council and implemented by the director of the program. A number of the members of the advisory committee were upset that the decision had been made without their action or approval, and they wanted to see the tribal council resolution that authorized the change, since they had never seen the document. The president of the advisory committee specifically stated that the senior advisory committee had never been notified of the change, and therefore he did not know whether serving people fifty-five to sixty had been properly authorized. 
Mid-American Review of Sociology

When he raised this in the meeting I told him that I had seen something recently that had authorized such a change in federal government regulations. $\mathrm{He}$ responded that he was aware that the federal government had authorized the change but that the tribal council of each tribe had to officially sanction it. I thought that it would be easy to satisfy his complaint by obtaining a copy of the tribal resolution for the senior advisory committee and obtaining a copy to get a copy. I followed this up after the meeting by going to see John Morgan at the tribal administrative office to request a copy of the tribal
council resolution.

Being rather naive, but trying to live up to the role of "problem-solver" I had been given, I suggested to John that if he wanted to smooth over past differences with the senior citizen advisory committee he should give them a copy of the tribal council resolution that officially lowered the eligibility for free meals from sixty to fifty-five. I thought that this was a simple way to solve what I saw as a minor problem, since the larger issue of who exercised power

I made this sul, and had been resolved in the tribal administration's favor. responded--with other peoplion to John in the tribal administrative office. John for their benefit as mine le around so that I knew he was saying it as much whether or mine--that "it is at the discretion of the tribal council provide the information if they copies of their resolutions and they would John's response gav they think it is appropriate."

interpret as intentio gave me the distinct impression, which I can only that everyone around the his part because it was said in a "public" voice so routine as I thought it the office could hear, that my suggestion was not as routine as I thought it was. Naturally, this embarrassing rebuke in public had its intended effect and I dropped the issue after being told this.

\section{RUNNING THE GAUNTLET}

In the absence of a tribal newspaper, information is passed on by word of mouth. In a relatively small community, this process is exceptionally fast. There is no doubt that my presence on the reservation was widely known spoke always asked, but even after months in the field everyone with whom I reservation when I I I was and questioned the purpose of my being on the reservation when I met them for the first time. I call this process of being shot at Oneu, and tests your mettle.

One must have a great deal of patience with this process, despite the likelihood that one will get tired of justifying oneself the longer one is in the descriptobably the most difficult aspect of these recurring conversations is the the advice given within the lite paradox of the situation is that if one follows the advice given within the literature to describe the project in general terms, purpose of the project in flat and trivial. It is obvious that describing the projose of the project in detail must be avoided either out of fear that one's informant who rells you or because of the danger of the all too obliging 120
Uninvited Researcher in Indian Country

identifies the motive behind a researcher's irritation as the desire to be recognized that "I am not as other men are." She considers this attempt to be accepted as a natural reaction, but she indicates that she no longer puts much effort into differentiating herself from the group with which her hosts identify her. This is good advice, but I would add that this irritation also comes from two other sources. First, from the discomfort of having to explain one's project within the constraints just discussed and secondly, from the fact that one is being forced to jump through hoops, since everyone knows who you are after a very short period of time.

Nonetheless, I was questioned about the purpose of my being on the reservation at each of the social service agencies I approached for information. After the first few times it happened I came to expect it whenever I approached anyone in a formal setting, although I never felt like I had perfected a response..$^{9}$ After I had been in the field for nearly two months I had an interesting experience that reveals the extent of this occurrence.

I had eaten lunch at the mealsite as usual and then went to the new location of the tribal administrative office to return the latest grant proposal for the forthcoming fiscal year's Title VI Nutrition program to the tribal planner. When I arrived I greeted his wife, who helped around the administrative office as a volunteer, and went in the next office to see him. When I stuck my head in the door John said that "I have had to explain to eighty-three people this afternoon what you were doing at the mealsite today." I said that I had been invited to eat the traditional meal ${ }^{10}$ and asked him if there had really been that many people who had asked about me.

Since he shared the office with the Tribal Enrollment Officer, I thought nothing of the presence of someone else, who was sitting in the office in the guest seat by the Enrollment Officer's desk. I did not know who he was but assumed he was there about some enrollment problem since he appeared to be waiting for the Enrollment Officer. This was not unusual since the tribe was expecting their last per capita payment for the settlement of land claims against the federal government and the rolls had to be updated and certified before the payment could be made.

In giving back the grant proposal I told John that Northern Drummer wanted a copy since she had to write the next fiscal year's grant, and he said she could have an extra copy he had. He asked whether there was anything in the grant proposal that we could make into a journal article that we had talked about writing together. I replied that the proposal "may be good for getting money but as social science it is lacking." In particular, I criticized the needs assessment upon which much of the data in the grant depended. ${ }^{11}$

After hearing this discussion the person in the corner asked me who I was and "what kind of work" I was doing on the reservation. I interpreted his tone of voice as containing an undercurrent of suspicion or hostility. I said I was a K.U. student and had been helping Northern Drummer with some senior citizen activities but that "I do not work on the reservation." John quickly came to my assistance and added that "I have been trying to get him on as a member of the Senior Citizen Advisory Committee." Not much was said other 
than this and shortly thereafter the person left. During the interchange the person never identified himself and I had no idea who he was until after he left when John informed me he was Big Badger, an important member of the tribal council.

After he had gone John told me that I should never introduce myself as a person from K.U. because of the lingering resentment against the socia scientist whose presence had previously generated controversy among tribal members, and the easy assumption that because I was at K.U. I was associated with him. John again repeated a piece of advice he had already given over a month earlier when I had first entered the field, that I should introduce myself as someone interested in gerontology since "no one would have problems with that."

After this I returned to the senior center to give Northern Drummer her copy of the Title VI grant proposal. I told Northern Drummer that "it seem like I am creating something of a stir up here because John said that he had to explain what I was doing to eighty-three people this afternoon." Northern Drummer responded "well that means you must be doing something good, people wouldn't be talkin' if you weren't doing something."

I said that I thought that this was one of the strangest places I had ever been in that "this was a community in which people really don't know very much about what is goin' on." Northern Drummer said that she thought it was just the opposite, that "everybody knew what everybody else is doing." She laughed as she said this.

\section{THE LEGITIMACY CRISIS}

Nine days after the above incident $I$ faced the biggest crisis of my fieldwork experience. After the meal hour had ended Northern Drummer called me aside to talk. She said that she and John had discussed my situation on the reservation and decided that it would be better if I were formally connected with the Senior Citizen's Advisory Committee. Their reasoning was that this would give me an excuse for asking questions, and make it easier on them because they would not have to explain what I was doing up there and why I was "trying to find out so much." Northern Drummer. said that she wanted to legitimize my presence because I could be useful to her, specifically mentioning my access to books and ability to help with a new needs assessment.

Being called aside to be told that my presence on the reservation was being questioned was difficult for me despite the fact that such a reaction is easily understandable, since there is good reason for Indians to be suspicious of anyone from outside their community. I sensed that perhaps the timing of my visit was bad because of the impending General Council meeting (analogous to a New. England town meeting) scheduled for the following day. Northern Drummer was concerned that perhaps someone would ask what I was doing on the reservation during the meeting and then she would have to answer for me. Despite my disappointment at not yet being accepted, I told Northern Drummer that "I realize that you and John are looking out for me." After talking with Northern Drummer I went to talk with John at the tribal administrative office as he had asked me to do when I saw him during lunch at the congregate meal site. When I arrived his wife, who was working that day as a volunteer, and one of the secretaries were sitting in the reception area. As soon as John's wife saw me she jumped up and went to his office to announce my arrival. Her actions were quite unusual since $I$ had never been shown around or announced before, but had always wandered back to his office on my own. Therefore, her actions only aroused my suspicion that something was amiss, since there was no reason to interpret the motivation behind her actions as normal. Trying not to act concerned, I stuck my head in the door and told John I would be back as soon as I went to the bathroom, which was out in the garage area of the administrative building. When I came out of the bathroom John was waiting there for me. This too was unusual and my fears about the project began to run wild.

John asked if I had talked with Northern Drummer. When I said that I had he seemed somewhat relieved but proceeded to discuss the matter further. John said several times that the atmosphere on the reservation was highly charged and unsettled because of the General Council meeting scheduled for the following day. John said that people had been talking about me asking why I was trying to find out about religion. He also said that there was a rumor going around that I was asking people questions about religion, and that my research project was really about their religion. I emphatically denied that this was true but conceded that if people talked to me about religion, which several had done at the senior center, I did not try to cut them off or try to avoid conversation about it. I did deny that I was going around asking questions about religion or that my research was on their religious practices. ${ }^{12}$

John then said that the same thing had been said about my asking questions about politics, and I admitted asking about that. My defense, although I am not sure I made myself clear to him, was that, when compared to religion, discussion of reservation politics was pervasive and something that could not be ignored. People talked about reservation politics openly in public, and because it was openly discussed, any researcher would encounter the politics of the reservation whether they were interested in it or not. Indeed, John had introduced me to many of the current political controversies on my first day in the field, and others let their sentiments be known about a variety of political issues of local concern. In contrast, religion did not appear at the surface of reservation life and I had not pried to discover it.

John said that the tribal chairperson, the executive officer, Northern Drummer, and he had been backing me whenever someone had asked about me but that this could get to be a problem for them and that the whole thing could be easily resolved if I were to become a "professional" member of the Title VI Senior Citizen Advisory Committee. I said that I had only one problem with such a role and would be concerned that I would become 
identified with one of the known political factions or groups, and that this would ruin my access to other people necessary for my study.

To make this whole conversation more unpleasant, while John and I were talking several people including a tribal council member and the tribal chairperson walked by us. I sensed that John was extremely concerned about what these people had overheard. I too was concerned because the very appearance of us talking "secretly" in the garage could not have been lost on any observer as they came and went from the bathroom. In fact, a couple of them, including the tribal chairperson, did hear the word religion mentioned several times. This made John extremely uncomfortable, but I could see no way to avoid discussing the issue openly without causing greater concern on the part of the person who overheard part of our conversation, since to act like we had something to hide or were concerned that people heard something that we did not want known would have been worse than anything we were actually discussing. Therefore, whenever someone walked by I did not lower my voice to keep them from overhearing our conversation because the last thing I wanted to do was act guilty or appear that I had anything to hide by whispering or falling silent when someone passed by us. Nevertheless, with John and I talking in the garage, it could not have looked like a completely normal or ordinary conversation, and I was concerned about how it might affect my project.

After we had discussed these matters for ten or fifteen minutes without resolving anything, John suggested that I not return to the reservation until the next meeting of the Senior Citizen Advisory Committee, which was to be held the following week. He also suggested that I only come up there once a month for that meeting for a few months, but I told him that if $I$ were to do that $I$ might as well call off my study. He agreed with me by saying that ${ }^{\text {it }}$ is the people who don't know you who are talking." He implied that even if the people who knew me thought I was trustworthy, the people who did not know me could hurt my research. The solution was to legitimize my presence with an official niche, a formal position within which I could operate. In order to convince me of this, since I hinted that I had some misgivings, he said that "there isn't room for informal relationships out here."

I said that "I had no problem with it," a phrase I had picked up on the reservation, but I expressed concern about gaining membership on the committee in an appropriate way, since I did not want to be perceived as John and Northern Drummer's appointee. I asked how professional members were chosen, whether they were elected by the group or appointed, and John said he was not sure.

Each of the incidents I have related reveals another ongoing process that is discussed in the literature. This is the dual process of how to present oneself and how one is defined by the participants. Both of these issues set limits on what the researcher can expect to learn. According to Jacobs (1977, p. 216), these two issues determine with whom the researcher comes into contact, the kinds of inquiries that are permissible, the meanings that are assigned to the inquiries, the kinds of information received, and the meanings imputed to the information--in short, "ultimately the validity and success of the project."

\section{THE FORCED ROLE OF THE RESEARCHER}

During my first week of fieldwork John gave me a piece of advice about how I should introduce myself. He told me not to identify myself as an academic, whether a sociologist or anthropologist, but as someone who is interested in gerontology. I considered this a perfectly practical and insightful piece of advice, but I found it difficult to do. I had accepted the advice given in the qualitative literature so completely and the researcher/academic identity had been an integral part of my self-concept for so long that I continued to introduce myself in this manner.

Moreover, from the very first day in the research setting I was defined in a number of ways. One of the roles that I was forced into was that of a "resource/problem solver." As a resource, I was asked to do a number of things, some of which I did and others that I refused. As examples of things I did: I wrote several letters to members of Congress for the Title VI Senior Citizen Advisory Committee, found out about the surplus commodity distribution program, gave short training sessions to the interviewers for the Title VI needs assessment, and wrote the National Indian Council on Aging for information about the Fifth National Indian Conference on Aging. In addition, I helped the director of the Title VI program put out a newsletter and wrote a brief summary of the preliminary results of the Title VI needs assessment for inclusion in the grant application requesting continued funding for the program. Among the things I was asked to do but did not feel comfortable doing: I was asked to write a grant outside of the tribal council and tribal administrative structure, I was asked by the Senior Citizen Advisory Committee to write a resolution to the tribal council protesting changes in the home deliveries and other complaints about the nutrition program, and I was asked to give an "in-service training session" to people in one of the social service agencies.

Since the reservation setting was characterized by political tensions and struggles I was also defined as a "potential ally" in these struggles. Some of the things I was asked to do would have embroiled me in these disputes, so I tried to maintain the role of resource person without taking sides in reservation politics. Both of these roles that I was assigned were generally positive, although from the perspective of the researcher each of them carries expectations that divert one from the primary research goals.

However, I was also assigned two negative roles--that of the "outsider/intruder" and the other as the "researcher" who was there to exploit the tribe. In fact, on my first visit to the multi-purpose senior center, I spoke with a woman in the library who asked if I was "writing a big paper." I did not understand that this is a nearly fatal admission in Indian Country. During this stage of fieldwork I learned that people did not like many of the things that had been written about the tribe, and people would joke with me about 
how much money I was going to make from my research and what were my plans for distributing the large sum of money I was going to make. Usually the joke was that I would have to buy everyone steak dinners.

\section{ROLE OF KEY INFORMANTS AND BROKERS}

After nine months of fieldwork I realized that unless I did something dramatic I would probably never finish the project. I knew a good deal about the reservation community and had made a number of acquaintances but had not "gathered my data." I understand this predicament as an example of being caught between two different cultural concepts of time. In other words, I was experiencing what Wax has characterized as the "limbo between two cultures" (Wax 1971, p. 42).

On the reservation, a different time consciousness pervades life. Time has no beginning, no end. It is continuous, enduring, undemarcated except for the coming of seasons (to which the religious ceremonies are tied) and the stages of the moon (which explains some social behaviors). Life is being rather than doing. Back at school, the Anglo concept of time--linear, fleeting, precisely divided, strictly monitored and harshly evaluated in terms of things accomplished--prevails. Time, the thing most precious and scarce, rules over life itself.

Every day I would begin my journey to the reservation imbued with this Anglo sense of time, filled with an urgency to accomplish, to push the project to a close, each time finding that life and time on the reservation has an intractable quality with a different measure and tempo. Finally, in frustration and desperation to gather my data, I decided I would pay people who would consent to be interviewed five or ten dollars for a completed interview. I asked several of my key informants what they thought of the idea and was surprised that they opposed it. The first thing that I was asked was whether I could afford it, to which I responded in all honesty that I could not. Both of the people I talked with agreed that I did not want to talk with anyone who was doing it only for the money. Since I believe that they knew better than I what the likely consequence of offering money would be, I dropped the idea.

Instead, a few days-later I indicated to two of the respected male elders whom I had gotten to know fairly well that I needed to talk to them. I asked to speak with them after the noon meal at the meal-site, after which we went into the small library that adjoins the dining area. Here I told them: "I need your help." I told them that I needed to complete my interviews and asked for their assistance. They both agreed to help, both gave me interviews, and within a few days they had lined up several more for me. I then gained the assistance of two other brokers who helped me arrange further interviews.

\section{CONCLUSION: REFLECTIONS ON FIELDWORK}

Among whites, a social science research project gives an individual researcher legitimacy. Among American Indians, the situation is reversed: a particular individual researcher gives the research project legitimacy. This particular individual resue of and operates with full impact on a research condition is especially true of and operates with paper details the ways in project conducted by an uninvited researcher. This paper details the ways in which my experience as an uninvited researcher in Indian Country differ from the research process chronicled in the qualitative methods literature.

For research conducted among American Indians, the general tenor of the For reatest discrepancies qualitative methods literature is misleading with the Only advice surrounding the issues of gatekeepers and the research bargain. Only advice on establishing rapport seemed to work the way the literature suggested, and on establishing rapo the uniquely Indian processes I have termed "Running the literature ignores the "Legitimacy Crisis." I believe that all uninvited the Gauntlet" and the "Legitimacy Crisis. I believe that all The more researchers working in Indian Country face these two obstacles. The more numerous and pervasive the gatekeepers, the more prolonged and piecemea the negotiation of the research bargain terms, the longer the process of the negotiation of the rese likelihood of facing a serious legitimacy crisis.

Looking back on the project, I believe that the first stage of fieldwork Looking back on the project, I believe that the may be motion without forward movement, the experience is not intrinsically satisfying, and there is forward movement, the experience long before any chance of rescue. Although a great danger that on a great deal, this stage is fraught with anxiety since one one is really learning a great deal, this stage is fraught with an

is aware of one's precarious connection to the community. Moreover, this initial stage las research among Native Americans can Therefe, it is an other group. Based on be done with as much dispatch as a project with any other group. Based on my experience, an uninvited researcher must expect to spend a minimum of six months establishing rapport and becoming accepted. My own and that of others suggest that nine months is more realistic.

In part, this is attributable to the absence of a hierarchical community In contradiction to the literature on fieldwork that presupposes hierarchical authority structure that can minimize resistance, I found that the "research bargain" among Native Americans is not a single event that is made research bargain am project with a person in power, but something that is at the outset of the project with a person in power, buth many people. negotiated and renegotiated over the course of the study with many people. Although the tribal chairperson told me what I would need to do in order to receive his permission, I found that the research bargain was an ongoing receive his permission, Informs regarding one's presence and process characterized by informal negotiations regarding on s pren" are not activities. Moreover, in American Indian communities "gatekeepers" are not only people who hold political office or even people who administer tribal
affairs or the social service agencies. The tendency is for each individual to act as a gatekeeper.

Although I have presented the multitude of gatekeepers as a problem, it does have a positive side. The positive side is that it is unlikely that any single does have a positive side. The positil sortion of the research setting to the person can close more than a small porton of the resily know the community inquiry. Moreover, the gatekeepers do not necessarse of my project, many as well as they think they do. During the course of my project, many individuals cautioned me about asking or doing something, saying that they did 
not think people would answer certain questions or would not feel comfortable with my project. One of the first elders I got to know, Lone Wolf, told me that I would have problems with my project. He said "the family is one of the most sensitive things out here." He continued by saying that asking questions about people's family "touches people's sensitivities" and that "people think they own their personal history." However, I found that the people like Lone Wolf who sought to give me directions were among the most cautious and circumspect of my respondents, and with very few exceptions, people freely shared their life stories even to the point of revealing things they realized were not consistent with abstract Anglo morality.

The start of conducting formal interviews, which took two and a half months to complete, marks the transition to the stage when I was able to concentrate on my project. However, by the time I began interviewing I had already revised the scope, character and emphasis of my project. During the first stage of fieldwork, I came to recognize that the history of the tribe and the reservation community were integral to an understanding of the aging experience of this group of elders (see Moore 1976). Indeed, all of their current struggles to provide services and develop the reservation are a direct outgrowth of this history.

In addition, my project was also modified in the direction of paying greater attention to the formal social service supports that existed on the reservation. In part, this aspect assumed greater importance because I became involved with part of this service network through my knowledge of the Title VI nutrition program. Because of my involvement with this program, I broadened my data base to include two surveys of Indian elders service needs in addition to the survey I administered on family life and informal supports.

What, then, should a researcher expect when conducting research in a Native American community? First, conducting research among American Indians is a unique undertaking, especially when the researcher is uninvited The researcher should anticipate that the project will take longer than other qualitative research projects to complete. This is attributable to a number of factors. Among these, American Indians view outsiders with suspicion, rapport factors. Among these, American Indians view outsiders with suspicion, rapport must be built up through personal contact over a considerable period of time, and few-American Indians view social science research as a worthy activity. This combination of factors means that the research bargain is a constant process negotiated with a number of individuals who play the role of gatekeeper, attempting to control one's access to either information or people.

Despite these difficulties, it is possible for the "uninvited" researcher to conduct research among American Indians if one is willing to show patience, sensitivity, and perseverance. Moreover, one must expect to get involved, positively and negatively, with one's hosts. As I found out, nothing about one's presence is viewed neutrally. In addition, a researcher can also expect to become the object of jokes. This too is both positive can also expect to maintaining a sense of humor is important and establishing a joking relationship with others about oneself and the research will do much to defuse the threatening nature of social science research. Indeed a much to defuse to recognize that social science research has no intrinsic validity from the American Indian viewpoint and the credibility of the project is inversely related to its theoretical importance. Applied research projects will fare much better than projects intending to address abstract theoretical issues.

Therefore, a researcher needs to maintain a flexible approach about the issues that will be part of the research project so that one's hosts can help define aspects of the project. This accommodation can take many forms, but allowing one's hosts to define research issues or explain what they feel is important to know about their individual and collective experience is completely consistent with the goal of understanding people on their own terms.

\section{ENDNOTES}

1. This study was conducted on the Prairie Band Potawatomi reservation in northeastern Kansas. It is located about twenty miles north of the state capital of Topeka. It is the largest of the four Indian reservations in Kansas, in both land area and Indian population. The Prairie Band are a people who value their privacy, traditions and independence. They are generally recognized as one of the most conservative of the Potawatom subgroups. Altogether, I spent approximately one year in intensive fieldwork, during which I conducted both formal and informal interviews, attended public meetings and community events. This was supplemented by another year of occasional trips to the reservation, informal contacts with tribal members, as well as telephone conversations with people with whom I had established closest contact. All of this fieldwork occurred between 1982-85. With few exceptions, most of my fieldwork was conducted during weekdays during normal working hours. I made a handful of other visits at night or on weekends, but my homebase on the reservation was the senior citizens' congregate meal site, which only operates five days a week. I estimate that I spent nearly seven hundred hours on the reservation engaged in this research project. However, only about ten percent of this time was spent conducting the family interviews that were the object of the research project.

2. For all their merits, two good examples of this are works by Robert Bogdan and Steven J. Taylor (1975) and John Lofland (1971). I should make it clear that my criticism of their books is that a person may too easily get the impression that fieldwork is accomplished by the practice of a fixed set of techniques in well-delineated stages. The authors do warn against this impression, although not forcefully enough, since major portions of these texts are offered to the reader as a "How To" conduct research.

3. John Lofland (1971, p. 108) uses the term "compulsion" to characterize the discipline and dedication necessary to succeed at the unrewarding task 


\section{Mid-American Review of Sociology}

of recording one's experiences. Rosalie Wax $(1971$, p. 17, 20) stresses the uniqueness of the "dialectic" between each researcher and research setting and also challenges the notion that mastery of the "rules of fieldwork" has any special status in conducting a research project. According to Wax (1971, p. 15), "a researcher cannot simply learn a few basic 'rules of fieldwork,' drop himself among an alien people like a man from Mars, and then proceed to acquire understanding."

4. I would like to make it clear that even this delineation of stages is an analytic one.

5. Although a disguised role was not possible, I doubt whether it would have been an advantage. As Colen and McNeely (1983, p. 17) recognize,
"minority researchers meet with their own brand of resistance." In this community anyone who is not a long-time member automatically has the status of an outsider. Undoubtedly, a disguised researcher would have been able to collect some information that I could not, particularly the relationship between "traditional" religious practices and family life, and probably would have been able to observe a greater measure of the intimacy of family life. However, I think that this person would have worked under a different set of constraints than I did, having to be more opportunistic in gathering information and very concerned that they were asking too many questions. Because of this, I believe that the project would have taken longer to complete since the disguised observer would have had a difficult time getting information that people do not normally discuss. Such things as a systematic residence history, frequency and types of contacts with each sibling and child would have been impossible to collect for more than a handful of people. In addition to these analytic problems, the disguised observer would have confronted a number of vexing ethical concerns.

6. Rosalie Wax (1971, p. 368) mentions a similar situation she encountered when she was told of problems and asked for advice on how to solve them. I will have more to say about being put in this role when I deal with the topic of how I was defined by my hosts.

7. In retrospect, I cannot decide whether my decision not to interview her aunts was a wise one, since they did refuse to be interviewed later when both she and I asked them on several occasions. However, since I did not know anyone except the three tribal officials, I was reluctant to accept her offer until I understood more about the research setting and the people. In particular, I did not want to conduct a couple of interviews until I was sure I could get the twenty or so I felt were necessary for this portion of my project.

\section{Uninvited Researcher in Indian Country}

8. This strategy would have been impossible for structural reasons as well as the general distrust of social science research. With the exception of the the general distrust of social science research. With the dians are spread two (now three) "cluster sites" of Indian homes, many Indians are spread out over the reservation interspersed with whites. This is especially true of the elders, who have typically not been chosen to move into these of the elders, who have typically not been have a HUD home built on HUD cluster homes or have preferred to hav know which homes were their own land. Since a researcher would not know which homes were

households containing an Indian elder, and there is no "rest home" on
near the reservation, it was not possible to sample elders in this way.

9. I am not suggesting that a researcher come up with a "canned" speech about the project. This would surely put people off because few academics are good enough actors to deliver the lines convincingly. One must simply are good enough actors to delact with your host in a spontaneous manner. tolerate the anxiety and interact with your host in a so concerned with the My feeling is that Native Americans are not so much concerned with the topic of the research project (with the exception of research on their something about a researcher's character.

10. Northern Drummer called this a traditional Indian feast. The meal consisted of corn soup (a beef broth base with diced beef, hominy and consisted of corn soup (a beef (a semi-sweet flat bread with a chewy kernels of corn), fry bread (a semi-sweet flat , beef chunks in gravy, and consistency), a bolled pot (smak for Indian pumpkin (which I mistook for baked arison and sweetened with brown sugar), along with iced tea or coffee.

11. These were the same survey results the tribal planner gave me during our first meeting. Among the problems, it did not provide any indication of the results were based, much less an indication of how important demographic differences effected these results.

12. It is interesting to note how little this sensitivity about- religion has changed during the twentieth century. Although he was writing about the previous predominant spiritual practices (clan and medicine society rituals), according to Alanson Skinner (1924, p. 61):

The [Prairie Band] prove most conservative and unwilling The informants on matters of risiting and this whom the writer has had the privilege of visiting, and this statement applies to tribes of Iroquoian and Siouan stock as well, for while most are hesitant, to say the least, none have been so difficult and, for that matter disagreeable to approach. 
It is not that the Prairie Band simply will not share their religious beliefs and practices with others. Skinner (1924-27), Landes (1970), Clifton (1969), and Bee (1964) all learned about aspects of their religious beliefs and rituals. However, most Prairie Band members guard that such knowledge is not passed indiscriminately to people who are there to exploit them. The result is that the researcher must gain the trust of the people who control access to this knowledge.

13. Other researchers in Native American communities have encountered much the same situation as I did, and corroborate my own experience. Indeed, as the following examples attest, this six to nine month period of gaining acceptance is pervasive and well may be universal. For example, a Professor DeCesare was quoted as saying of her research experience among the Cocopah: "Most American Indians are not particularly friendly to outsiders. It took six to eight months to earn their trust. In the interim, I collected their myths and legends while I was waiting to hear their music" (Lawrence Journal World, December 24, 1984). Prior to the start of my project I visited several researchers who had worked among the Kickapoo. They said that they would be happy to introduce me to the "influential people" in order to expedite gaining access and acceptance in this community. They said that it had taken them a long time to gain the trust of the people, and that with their help it would not take the "nine months or so" that it had taken them to get the Kickapoo's cooperation. Since I did not know them very well and was not ready to enter the field at the time I never took them up on their offer.

14. Some proponents of quantitative methods view this situation as compromising qualitative research since it appears to damage the "representativeness" of the study. The issue of bias introduced by nonresponse is hardly unique to qualitative methods, however. Obviously, nonrespondents can hurt both types of research. One can argue that qualitative methods overcomes this problem just as well as quantitative methods because of the profound nature of the research involvement.

\section{REFERENCES}

Becker, Howard S. 1970. Sociological Work: Method and Substance. Chicago: Aldine.

Bee, Robert L. 1964. "Potawatomi Peyotism: The Influence of Traditional Patterns." Southwestern Journal of Anthropology 22:194-205.

Bogdan, Robert. 1972. Participant Observation in Organizational Settings. Syracuse, NY: Syracuse University Press.

Bogdan, Robert and Steven J. Taylor. 1975. Introduction to Qualitative Research Methods: A Phenomenological Approach to the Social Sciences. New York: Wiley.
Clifton, James A. 1969. "Sociocultural Dynamics of the Prairie Potawatomi Drum Cult." Plains Anthropologist 14:85-93.

Colen, John N. and R. L. McNeely. 1983. "Minority Aging and Knowledge In the Social Professions: Overview of a Problem." Pp. 15-23 in Aging in the Social Professions: Oby R. L. McNeely and John N. Colen. Beverly Hills, CA: Sage.

Curley, (1) 223-26 in Minority Aging Research: Old Issues--New Tribes'." Pp. 223-26 in Mercil Stanford. San Diego, CA: San Diego State University.

Gold, Raymond L. 1969. "Roles In Sociological Field Observations." Pp. 30-39 in Issues in Participant Observation: $A$ Text and Reader, edited by George J. McCall and J. L. Simmons. Reading, MA: Addison-Wesley.

George J. M. 1977. Stateville: The Penitentiary in Mass Society. Chicago: University of Chicago Press.

Landes, Ruth 1970. The Prairie Potawatomi: Tradition and Ritual in the Twentieth Century. Madison: University of Wisconsin Press.

Twentieth Centing Analyzing Social Settings: A Guide to Qualitative Lofland, John. 1971. Analyzing Social Selling. A Gorth. Observation and Analysis. Belmont, CA: Wadsworth.

Maynard, Eileen. 1974. "The Growing Negative Image of the Ant Among American Indians." Human Organization 3 .4inority Aging." Pp.

Moore, Joan W. 1976. "Situational Factors Affecting Minority Aging. Pp. 321-27 in Contemporary Social Gerontology: Significant Developments the Field of Aging, edited by Bill D. Bell. Springfield, LL. Charles C. Thomas.

National Indian Council on Aging. 1981. American Indian Elderly: A National Profile. Albuquerque, NM: National Indian Council on Aging.

Proflle. Alohn G. 1982. "American Indian and Alaskan Native Elders: A Red Horse, John G. 1982. "American Indian and Alatus of Minority Aging, Policy Critique." Pp. 15-26 in Trends and Status of Miego, CA: San edited by E. Percil Stanford and Shirley A. Lockery. San Diego, CA: San
Diego State University.

Skinner, Alanson. 1924-27. "The Mascoutens or Prairie Potawatomi Bulletin of the Public Museum of the City of Milwaukee Vol. 6, nos.
2,3.

Stack, Carol B. 1974. All Our Kin: Strategies for Survival in a Black Community. New York: Harper.

Trimble Jos Men Methodological Issues and Concerns. Wornings and Advice. Chicago:

Wax, Rosalie H. 1971. Doing Fieh University of Chicago Press.

Wiseman, Jacqueline P. 1970. Stations of the Lost. The 